UDC $316.774+314.74$

Yuzva, L., Tashchenko, A. (2021). «But Don't Quote Me on That»: How Ukrainian Top Media Characterized the Perception of Migration and Migrants. Sociological Studios, 1 (18), 58-65. https://doi.org/10.29038/ 2306-3971-2021-01-58-65

\title{
«But Don't Quote Me on That»: How Ukrainian Top Media Characterized the Perception of Migration and Migrants
}

\author{
Liudmyla Yuzva - \\ Candidate of Sociological Sciences, \\ Associate Professor, Department \\ of Methodology and Methods \\ of Sociological Research, Taras \\ Shevchenko National University \\ of Kyiv, Ukraine \\ E-mail: luydmilay@ukr.net \\ ORCID: https://orcid.org/0000-0003- \\ $1448-5478$
}

\author{
Anna Tashchenko - \\ Candidate of Sociological Sciences, \\ Associate Professor, Department \\ of Social Structures and Social \\ Relations, Taras Shevchenko \\ National University of Kyiv, Ukraine \\ E-mail: anna.iuriivna@gmail.com \\ ORCID: https://orcid.org/0000-0002- \\ 6038-7337
}

DOI: $10.29038 / 2306-3971-2021-01-58$ 65

Received: May, 2021

$1^{\text {st }}$ Revision: May, 2021

Accepted: June, 2021
Ukraine finds itself in the countries of the Global North, which means that it adopts the formulation of its typical research questions like the current migration research landscape. Existing research are heavily skewed towards the Global North, where governments and international organizations increasingly fund them to inform policy development. Thus, migration provides the relevance of the study of discourses around the body of concepts on it. The article describes the subtexts of media characterising the perception of migration by migrants themselves and the perception of migrants by host side. With using the Mediateka tool, an automated sample of 39,000 reports on various groups of migrants was received in the TOP15 of the Ukrainian media (print media, TV channels, informational online media) from 2015 to 2018. The sample consisted of 12,000 messages, every tenth of which was selected for further in-depth analysis. The research was based on qualitative content analysis and critical discourse analysis. The six steps were done: looking at the description of the migration as objective necessity, subjective aspiration and something meaningless, and looking at the description of migrants as decent people, indecent people and just people with some lifestyle. The latent meanings of the messages, where the leading Ukrainian media touched on the perception of migration and migrants, were divergent and contradictory; they could not become the basis for confidence in any permanent characteristics of the images of migrants. As one of the most interesting prospects for further research, it may be the test of whether those transmitted meanings, which are usually considered positive, can interfere with social integration, and vice versa - whether negative meanings can help it. This can be done on the basis of additional empirical research using quantitative methods, such as cluster analysis to check which groups media consumers might be divided into after receiving the information about migrants.

Key words: migrant, discourse about migrants, media messages, qualitative content analysis, critical discourse analysis.

Юзва Людмила, Тащенко Анна. «Але це неточно»: як в українських топ-медіа характеризували сприйняття міграції та мігрантів. Метою запропонованого дослідження є розкриття груп латентних смислів у медіаповідомленнях, що описують проблеми сприйняття міграції й мігрантів. Увагу приділено розгляду підтекстів інформації, що характеризують сприйняття міграції мігрантами та сприйняття мігрантів стороною, котра приймає. Дослідження грунтувалося на якісному контент-аналізі та критичному дискурс-аналізі. За допомогою інструменту Mediateka отримано автоматизований масив iз 39 тисяч повідомлень про різні групи мігрантів у ТОП-15 українських ЗМІ (друкована преса, телеканали, інформаційні онлайн-видання) 32015 по 2018 р. Вибіркова сукупність становила 12 тис. повідомлень, кожне десяте 3 яких відібрано для подальшого поглибленого аналізу. Проаналізовано описи міграції як об'єктивної необхідності, суб'єктивного прагнення й безглуздя, а також описи мігрантів як людей порядних, непорядних і таких, які просто мають певний стиль життя. Основним висновком є те, що латентні смисли повідомлень, де провідні українські 3МІ зачіпали тему сприйняття міграції та мігрантів, були різноспрямованими й суперечливими, що логічно та очікувано пов'язано із загальною недовірою, значною соціальною дистанцією і мігрантофобією в українському суспільстві.

Ключові слова: мігрант, дискурс про мігрантів, медіаповідомлення, якісний контент-аналіз, критичний дискурс-аналіз. 


\section{SCIENTIFIC PROBLEM AND THE RELEVANCE OF THE RESEARCH}

The media is a soft power, and the way they cover a particular piece of information is especially important. Among other issues, migration is widely covered by media channels, as it is a pervasive phenomenon in a globalised world. The level of social integration, stability in a migrant-filled society, national distance, biased identification of others could all depend on this coverage. Thus, the study of discourses around the body of complex and trendy concepts of the migration field becomes relevant.

The Ukrainian society continues organising, migrating, meeting migrants, and dealing with the media reports about migrants. At the same time, Ukrainians both adapt to and reproduce social conditions unfavorable for existence: double institutionalisation, distrust in many social institutions, anomic demoralisation, cynicism, strong national distancing, negative identification (Golovakha, 2014, 2015; Dembitskyi, 2019), etc. Broadly speaking, Ukraine finds itself in the countries of the Global North, which means that it adopts the formulation of its typical research questions: «The current migration research landscape is heavily skewed towards the Global North where existing research is largely designed and led, and where governments and international organisations increasingly fund research to inform policy development. The Global North's interests shape dominant research themes, producing a disproportionate focus on South-North migration (SNM) and categories of migrant defined in law and policy to make sense of - and increasingly contain - migration flows. Epistemic communities concerned with migration are largely produced and reproduced in and by the Global North: while ODA-recipient countries host a growing number of research centers, most researchers are trained in the Global North» (IASFM18..., 2021). But our experience of presenting the research of media discourse on migration and migrants (within the international research project «Migrants. Analysis of media discourse on migrants in Poland, Great Britain, Ukraine, Albania and the Czech Republic» ${ }^{1}$ we are involved in) testifies to the recognition of the special position of Ukraine in the imagination of the scientific community. Its essence was very aptly stated at one of the conferences by one of our reviewers: our country is not ordinary - in the sense that it gives migrants away rather than letting them in, but at the same time it is the subject of research as a country that receives migrants.

All the mentioned lines converge on the point of one question: what media images of migrants can society offer itself while it is disoriented and following the studying trend which it feels differently than more economically developed countries?

\section{ANALYSIS OF RESEARCH AND PUBLICATIONS, THEORETICAL FRAMEWORK, METHODOLOGY, EMPIRICAL DATABASE}

Since we have been working on the project for a long time, some reviews of the relevant literature have already been made and even discussed (Tashchenko, 2020). However, let's be clear about what the previous studies were lacking and what we were looking to offer in addition to them. One of the first (in chronological order) studies we met was the audit of Ukrainian media information on the topic of EU visa policy and visa liberalisation processes. It revealed in what form the issue of visa problems was mentioned in the publications on the topic of external labor migration of Ukrainians. Among other things, these were warning about visa fraud cases and, at the same time, recommending semi-legal employment schemes with a description of specific real experiences (Parkhomenko, 2011a, 2011b), and this can not only push to violate the law, but also distort the readers' impression of the moral character of migrants. The results of this audit have been addressed with narrow migration issues.

Another study, which we were interested in, had been conducted by «Fama» (the presentation of results is in (Topol, 2015)). The part of it was devoted to prejudice against internally displaced persons and refugees. It revealed that Ukrainians predominantly disagreed with the so-called fact that only bandits left

${ }^{1}$ MAD. COLLEGIUM CIVITAS, higher education school, entered in the register of non-public universities maintained by the Minister of Science and Higher Education under number 129, TAX ID 525-20-83-784, statistic number 012769984, with headquarters in Warsaw, 00-901 Warsaw, Poland, XII floor, Palace of Culture and Science, Defilad Square). The Project is financed by the National Academic Exchange Agency as part of the «Academic International Partnerships» Program based on Decision No. PPI/APM/2018/1/00019/DEC/1. The amount of funds allocated to the Project Leader for the Project implementation is PLN 746480. 
the Ukrainian-controlled areas of Donbas. But it also indicated a considerable concern of those, who did not contact the IDPs directly, about the possibility of conflict, social tension and the worsening of crime situation. The other results showed that about a third of Ukrainians considered migrants to be competitors in the education, labor and real estate markets, as well as dependents who refuse to work (Tarasenko, 2015). The data obtained in this study referred to the specific case of internal migration in Ukraine.

Some tasks of our project were close to ones presented in the digest being prepared as part of the project «Promoting evidence-based media coverage of labour migration from Ukraine to V4 countries» (Poland, Hungary, Slovakia and Czech Republic). Its purpose was to characterise the reflections of labor migration in the media. In particular, it has been found that in the media the topic of labor migration and its negatives were used for manipulative purposes by both Russian/ pro-Russian media or individual speakers and opposition for criticism of the authorities, and there were no important topics such as, for example, minimising the negative effects of labor migration and the development of positive effects (Myths..., 2019). This digest focuses on one type of migration.

As more relevant to our interests, there were found two studies devoted to the analysis of discourse on migration processes in Ukrainian Internet media based on «Ukraiins'ka pravda», «Dzerkalo tyzhnia» and «Korespondent» (Senchylo, 2018) and critical analysis of discourse about IDPs in national official vs. alternative and regional official vs. alternative media based on «Holos Ukraiiny», «Dzerkalo tyzhnya», «Kharkivs'ki visti» and «Media Port» (Protsenko, 2018). The empirical base was restricted but some important worrying trends were highlighted - in particular, dominance in the headings and subheadings in the online media of lexical units associated with negative emotions/ feelings and contrasting the local population, authorities and volunteers as «good» ones and the IDPs as «helpless» ones, etc. With all the advantages of these studies, our plans were wider - firstly, to reach the printed media, television and the Internet, and, secondly, to look at the picture of migration and migrants in general.

Our research perspective is based on sociological discourse analysis as it was formulated by J. J. Ruiz: «In order to interpret discourse from a sociological standpoint, discourse must first be analysed from both a textual and a contextual approach. There are three different levels of analysis: a textual level, a contextual level and an interpretive level. Although text- and context-based analyses are elements of sociological discourse analysis, they are not in themselves sociological analyses. Textual analysis allows us to characterise discourse as it focuses chiefly on the utterance and considers the discourse as an object of study. Contextual analysis, on the other hand, allows us to understand discourse as it centers on the enunciation, considering the discourse as a singular act or event. Finally, interpretation provides an explanation of the discourse as it addresses sociological aspects and considers discourse as information, ideology or a social product» (Ruiz, 2009). The empirical basis of our research is a large sample: we use the data sample obtained from 15 Ukrainian top media (Uriadovyi kur"yer, Vesti, Segodnia, Den', Gazeta po-ukraiins'ky, UA:Pershyi, Ukraiina, 1+1, Inter, ICTV, Ukraiins'ka pravda, Tsenzor.net, Radio Svoboda, Strana, 24.ua) from 2015 to 2018 in the abovementioned project «MAD».

The general population of messages (12 thousand messages) was obtained automatically using the Mediateka and contained more than 39,000 publications with mentioning keywords (related to migration, migrants, refugees, IDPs, zarobitchany ${ }^{l}$ ). Such a partly mapped structure of the channels which the messages were subsequently included from could provide a slightly different methodology for their study (Yuzva, 2017). Therefore, were used the mixed methods. Quantitative content analysis showed the dynamics of the emergence of various topics related to migrants, and qualitative content analysis was used for better disclosure of the meaning of messages by sampled media. Now we want to focus on the results we got by applying the qualitative content analysis to a sample of media texts from every February in 20152018 and looking for relatively independent groups of «implicit meanings» (van Dijk, 2011, p. 6) while interpreting media discourse as ideology, what makes interpretation as the third level of sociological discourse analysis related to critical discourse analysis. The analysis categories were the perception of migration by migrants themselves and the perception of migrants by host side, and the analysis units were every tenth publications in the general sample (duplicates and only casually touching migrants/ migration

\footnotetext{
${ }^{1}$ The name is given in the national transcription as a nationally-labeled concept.
} 
texts were avoided). Latent coding was used, we took into account all possible subtexts of the discourse on migrants. 355 texts were encoded in this way.

\section{RESEARCH AIM AND TASKS}

We intend to reveal the types of hidden meanings in media messages, which describe the issues of perception of migrants and migration. So, we will consider the subtexts of media characterising it, and we have six steps to go through: looking at the description of the migration as an objective necessity, subjective aspiration and something meaningless, and looking at the description of migrants as a decent people, indecent people and just people with some lifestyle. The corresponding research question arose in connection with the expert characterisation of media messaging in Ukraine: «In conditions of war, the mass media inertially cover topics related to vulnerable groups, do not know how to deeply develop socially painful topics, in materials about vulnerable groups do not follow the balance of opinions and completeness» (Human rights..., 2018, c. 6). Migrants are one of the vulnerable groups, so we wanted to clarify what specific problematic meanings can be found in the descriptions of the perception of migration and migrants.

\section{MAIN RESEARCH MATERIAL WITH VALIDATION OF RESULTS}

\subsection{Migration as an Objective Necessity}

In the case of describing migration as an objective necessity for migrants, a stable «red thread» throughout all four years was the mention of wars that forced people to migrate. It would have been suspicious if corresponding implication had disappeared, because wars do happen and the media are obliged to inform about them. Here are some examples from the media:

- Settlers are fleeing war. Hoping to escape, they come to the liberated Artemivs'k or Kramators'k. And the worst thing is when the war overtakes them there (ICTV, February 2015).

- He [Herbert McMaster] accused Russia of financing the right-wing populist parties in Europe and sparking the war in Syria, leading to numerous human casualties and a large flow of refugees to the EU (Uriadovyi kur"yer, February 2017).

Now we propose to consider what groups of implications we found at all:

1. «Be shocked by how the war got migrants hooked»: migrants were reported to have lost their homes/ jobs/ job opportunities and strived to survive, escape war, find a new home and any job in unfamiliar living conditions.

2. «Migrants are victims of vile authorities»: migrants were reported to have experienced force/ administrative pressure in their native places.

3. «Migrants are victims of the economic crisis»: migrants were reported to have experienced decline in their own well-being and the well-being of their families.

4. «Let's pretend nothing is happening»: it was messaged that migrants had had to migrate, and the reason was not directly named, but lied on the surface (war; unwillingness of host side to be responsible for refugees).

5. «Someone is raving about political persecution»: it was about the vicissitudes of Ukrainian politician Anatolii Sharii, and, despite the tragic situation, an immunity to particular strangers' attempts to complain was encouraged.

\subsection{Migration as a Subjective Aspiration}

In the case of describing migration as a subjective aspiration of migrants, there were only few texts no so many texts and no systematically repeated implications. They referred to higher levels of needs, and consuming appropriate media messages may be of interest to most people in a society where basic needs are met. Otherwise, migrants' stories with similar impulses may be perceived as an analogue of some legends or even fairy tales. Here are some quotes from the media:

- When things happen beyond my will, I have an inner resistance. What happened is called occupation (Inter, February 2015).

- For me, emigration is_like a new life. Feel free enough because there are no borders in the European Union (1+1, February 2018).

Here are a few groups of implications at all: 
1. «Migrants are ideological heroes»: it was about the fact that migrants had realized the importance of defining the situation and made the difficult decision to migrate based on ideological considerations.

2. «Migrants are dedicated people»: it was about the fact that migration had been the fulfillment of the relative's last will and that migrants would have fought for a normal life exactly where they had already arrived.

3. «Migrants want to become a humans»: it was about a desire to go to school and get education.

\subsection{Migration as Something Meaningless}

In the case of describing migration as something meaningless, one and only implication manifested itself only once at Segodnia (February 2016), and it could be called «How to migrate without looking like a fleeing rat». It was about how one migrant had claimed the unwillingness to leave the country («I did not want to leave Ukraine»), but leaving actually happened (because a relative «accidentally found a place for $m e »)$. However, we should note that in Ukraine the «justification» of mobility opportunities is quite common in the case of realizing their superiority over the opportunities of others.

\subsection{Migrants as a Decent People}

The benevolent mood of the host side towards migrants' communication portrait (i.e., perceiving them as decent people) was reflected mostly in implications touched the common reasons to feel sorry for migrants or to perceive each of them as a rather good person. Let's go directly to the media for a start:

- The only thing I could never do is to fire on unarmed people. $<\ldots>$ I repeat this again for the prosecution and for the court: I could not fire at refugees (UA:Pershyi, February 2016).

- God, forbid anyone in their native land to become displaced without work, without housing, without livelihood (Ukraiina, February 2018).

Now let's go through the groups of implications at all:

1. «Migrants deserve sympathy»: there were messages in the spirit of an invitation to understand the pain, situation and desires of migrants as well as to get acquainted with examples of such understanding because first of all migrants are human ones.

2. «Migrants teach us good things»: there were messages in the spirit of admiration that migrants had been doing good deeds beyond the expected measure and showing extraordinary examples of kindness.

3. «Migrants are real and moral»: there were messages in the spirit of convincing that migration did exist, migrants were not «the dead souls» and many migrants were honest people who suffered losses due to the fact they had been suspected of dishonesty.

4. «Someone plays games, and a bad reputation goes to migrants»: there were messages in the spirit of indignation that migrants had been slandered and punished without any objective grounds.

5. «Some tolerance is possible»: there were messages in the spirit of admitting that migrants were treated well/ joyfully, but only within certain boundaries - that is, for the host side it was about more a lack of dislike than about liking, or about good manners/ curiosity.

Actually, the last one is already quite commendable in relation to media messaging. The call to express sympathy corresponds to the general rules of human communication, and, at the same time, we find a rational kernel in the idea of broadcasting that tolerance towards migrants may not be all-encompassing and this is not a tragedy. It would be much worse for society and its media to promise that all migrants are exclusively nice people, and then disentangle the results of the imposed idealisation.

\subsection{Migrants as an Indecent People}

As for reflecting migrants' indecentness, surprisingly nothing was found in February-2015 messages and from 2016 to 2018 the most frequently emerged implications were associated with labeling migrants as disgusting and superfluous. A lot of unpleasant things were latently expressed about migrants: «they hide, they bring stress, they are invaders, they annoy, it is difficult to communicate with them, they are enemies, everyone suffers from them, they are terrible, and they drove others to aggression, don't let them, forbid, take away, limit...»We will confine ourselves to one, but very eloquent quote from the media: «However, the locals are radically opposed. In their view, Syrians, Afghans and Nigerians occupied the city. Therefore, 
in Calais there were several loud protests. Slums have grown to the size of a town. There is a mosque, restaurants and a theater. And this frankly annoys the French» (24.ua, February 2016). The negative attitudes shown were concrete, and this is a reason to worry, because concrete indications of a 'problem' can easily outweigh general appeals for sympathy and partial tolerance. And if in general, then the following groups of implications were found:

1. «Migrants and their behavior are disgusting»: there were messages about unacceptability/ inadmissibility of a very wide range of migrants' actions, and they were rich in emotional and moral assessments of migrants themselves, their arrival and their settling in a new place.

2. «Migrants are manipulators»: there were messages in a spirit of condemnation for doing illegal or immoral things and accusing others of unrealistic crimes or waiting for happiness on someone else's unhappiness.

3. «Some migrants demand a lot»: it was about vulnerable sociodemographic groups among migrants and evaluating them as «consumers» who gave nothing in return or gave less to the host side.

4. «Some migrants are only visited by fools»: it was a very specific story about the trial of Ukrainian pilot Nadia Savchenko and her interaction with refugees.

5. «Some migrants are superfluous»: these were messages in the spirit of informing that societies were not prepared for such a test, migrants appeared in indecently large numbers and not all of them deserved to be welcomed.

6. «Some migrants are not interesting»: it was about Ukrainian internal refugees/ IDPs - in fact, they were told not to have had enough interest from the government and the media, and not to have withstood the unspoken ideological competition of images with images of other migrants; hence, it is easy to conclude that they were «indecent» by the very fact of their existence.

7. «Some migrants are less than human»: it was a message in the spirit of a warning that some labor migrants should not have even counted on equal treatment from the host side.

\subsection{Migrants as Just People with Some Lifestyle}

When migrants were described simply as people with some lifestyle, the media told us about the employment and qualifications of migrants, about the places and buildings which they lived in, their leisure time spending, their pets, their routine life difficulties and their money management. In them we can find some moralising hints too, but there would already be a little more uncertainty about the goodness or badness of things. Rather, it is an invitation to a compassionate acquaintance with the varied circumstances of everyday life:

- There are no additional staff at the facility. The residents themselves work as cookers, security guards, builders, tutors. Here people avoid political disputes, and there is a "dry» law. There have been cases where people were evicted for violating these rules. Now 130 migrants are living in a boarding house, including more than 40 children (Radio Svoboda, February 2015).

- It's hard for young people like me to get on their feet after university (Segodnia, February 2016).

- Whole buses depart from Ivano-Frankivsk, L'viv, Rivne. Mostly they go to Poland, mostly they are people of working professions: builders, drivers, carpenters, locksmiths, seamstresses, cookers, mostly they are young people (ICTV, February 2018).

And, by the way, about empathy. In addition to the general line, we tried to reveal the essence of the difference between messaging in the most trusted/ popular and less trusted/ popular Ukrainian top media (Media Consumption..., 2018; The attitude..., 2018) while being interested in critical studies of objectified migrant identity (Saddiqa, Anwar, 2019). It turned out that the most trusted / popular ones had a tendency to latently objectifying non-Ukrainian migrants in other countries. The less trusted/ popular ones also had a tendency to latently objectifying Ukrainian immigrants and to latently empathizing with IDPs in Ukraine. But absolutely all categories of migrants mentioned in connection with the characteristics of their «communicational (in)attractiveness» were presented as both decent and indecent people and had got both objectified and pro-equal images in all media. We believe that for Ukrainian society as a one with social integration based on distrust (Sudakov, 2015, p. 66) as well as with attention-grabbing social distance and migrant-phobia (Kniazieva, Dolzhenko, 2018, p. 64) this is a circumstance quite supposed to have been confirmed. 


\section{CONCLUSIONS AND OUTLOOKS FOR RESEARCH IN THIS FIELD}

Thus, the implicit/ hidden meanings in the Ukrainian top media, which touched upon the topic of perception of migration and migrants, were divergent and contradictory. There were both dramatisations («Be shocked by how the war got migrants hooked», «Migrants are ideological heroes», «Migrants are dedicated people», «Migrants want to become a humans», «Migrants teach us good things», «Migrants and their behavior are disgusting», «Some migrants are superfluous») and ironising («Someone is raving about political persecution», «How to migrate without looking like a fleeing rat», «Some migrants are only visited by fools»), both the search for the guilty («Migrants are victims of vile authorities», «Migrants are victims of the economic crisis», «Someone plays games, and a bad reputation goes to migrants», «Migrants are manipulators», «Some migrants demand a lot», «Some migrants are not interesting», «Some migrants are less than human») and the search for a way out («Migrants are real and moral», "Some tolerance is possible») or smoothing of the situation («Migrants deserve sympathy», «Let's pretend nothing is happening»). On the other hand, there were always some dominant groups of implications that did not always seem functional for Ukrainian society. Therefore, as one of the most interesting prospects for further research, we see precisely the test of whether those transmitted meanings, which are usually considered positive, can interfere with social integration, and vice versa - whether negative meanings can help it. This can be done, for example, on the basis of additional empirical research using quantitative methods, such as cluster analysis to check which groups media consumers might be divided into after receiving the information about migrants.

\section{REFERENCES}

Dembitskyi, S. S. (2019). Normless Anomie Index (NLAI): Construction and Validation. Sociological Journal, 25(3), 8-25. https://doi.org/10.19181/socjour.2019.25.3.6673

Golovakha, Ye. (2014). «Social cynicism and anomie in Ukrainian society: general dynamics and recent changes» Ukrainian society: monitoring of social changes, 1(15), 49-56.

Golovakha, Ye. (2015). «Trends of changes in the Ukrainian society after the Maidan: lecture-discussion». Retrieved May 13, 2021 from https://sociology.knu.ua/uk/news/lekciya-diskusiya-profieigolovahi-na-temu-tendenciyizmin-v-ukrayinskomu-suspilstvi-pislya

«Human rights and mass media in Ukraine: Collection of lecture notes» (2018). Retrieved June 1, 2021 from https://zmina.ua/publication/prava-lyudyny-ta-mas-media-v-ukrayini/

IASFM18: Disrupting Theory, Unsettling Practice: Towards Transformative Forced Migration Scholarship and Policy. Retrieved May 7, 2021 from https://pheedloop.com/iasfm18/site/

Kniazieva, O., Dolzhenko, L. (2018). Attitude Towards Migrants in Europe and Ukraine: a Comparative Analysis (according to ESS - European Social Survey 2012, 2016). Odesa National University Herald. Sociology and Politics, Vol. 23, 1 (30), 58-67. http://dx.doi.org/10.18524/2304-1439.2018.1(30).145417

Media Consumption Survey in Ukraine 2018. Internews. Retrieved May 6, 2021 from https://internews.in.ua/wpcontent/uploads/2018/09/2018-MediaConsumSurvey_eng_FIN.pdf

Myths and facts on Ukrainian labor migration to the Visegrad group (2019). Europe without Barriers. Retrieved May 3, 2021 from https://europewb.org.ua/wp-content/uploads/2019/05/Giude-EN-fin.pdf

Parkhomenko, N. (2011a). «Visa issues and its coverage in the Ukrainian media (content analysis of publications in the media in June-August 2011). Part 1». CO «Europe without barriers». Retrieved May 20, 2021 from https://europewb.org.ua/vizova-problematika-ta-ii-vidobragennya-ykrainskix-media-kontent-analiz-pyblikaciiv-zmi-y-chervni-serpni-2011-roky-chastina-1/

Parkhomenko, N. (2011b). «Visa issues and its coverage in the Ukrainian media (content analysis of publications in the media in June-August 2011). Part 2». CO «Europe without barriers». Retrieved May 20, 2021 from https://europewb.org.ua/vizova-problematika-ta-ii-vidobragennya-ykrainskix-media-kontent-analiz-pyblikaciiv-zmi-y-chervni-serpni-2011-roky-chastina-2/

Protsenko, O. (2018). Image of internally displaced persons in media discourse: critical discourse-analysis of media messages. Odesa National University Herald. Sociology and Politics, Vol. 23, 1 (30), 122-130.

Ruiz, R. J. (2009). Sociological discourse analysis: Methods and logic. Forum Qualitative Sozialforschung, 10(2), 26. Retrieved May 11, 2021 from http://nbn-resolving.de/urn:nbn:de:0114-fqs0902263

Saddiqa, A. Anwar, N. (2019). Objectified Migrant Identity Through Multimodal Critical Discourse Analysis. Global Social Sciences Review, IV-I, 187-194. 10.31703/gssr.2019(IV-I).25. 
Senchylo, N. (2018). Message on migration and residents in the internet: media discourse features. Gumanitarna osvita $v$ tehničnih visìh navčal'nih zakladah, 38, 31-36.

Sudakov, V. (2015). Society without trust: innovation strategy of scientific study of complex sociological problem. Bulletin of Taras Shevchenko National University of Kyiv. Sociology, 1, 66-67.

Tarasenko, N. (2015). «The situation in Donbass in the discourse of the Ukrainian media». Ukraine: events, facts, comments, 21, 72-81. Retrieved April 3, 2021 from http://www.nbuviap.gov.ua/index.php?option=com_ content\&view=article \&id=1655: situatsiya-na-donbasi-u-diskursi-ukrajinskikh-zmi\&catid=8\&Itemid=350

Tashchenko, A. (2020). Understanding Migration and Migrants: To Look 'Under the Lantern' or Where It Was Lost? Sociology and Contemporary Social Transformations. Proceedings of the 13th International conference of students and young scholars. Kyiv, November 19-20, 2020, 101-107.

The attitude of Ukrainians to political information on Ukrainian TV channels (2018). Kyiv International Institute of Sociology. Retrieved April 25, 2021 from https://www.kiis.com.ua/?lang=eng\&cat=reports\&id=794\&page=1

Topol, V. (2015). «Half of Ukrainians do not believe in independent media». MediaSapiens. Retrieved April 10, 2021 from https://ms.detector.media/mediadoslidzhennya/post/14376/2015-10-10-polovyna-ukraintsiv-ne-viryt-unezalezhni-zmi/

van Dijk, T. (2011). Discourse studies and hermeneutics. Discourse Studies, 1-13. 10.1177\%2F1461445611412762

Yuzva, L. (2017). Features of content-analytical methodology of modern media research: on the example of printed and Internet sources. In: New Inequalities - New Conflicts: Ways to Overcome. Abstracts and speeches of the participants of the 3rd Congress of the Sociological Association of Ukraine. Kharkiv, October 12-13, 2017, 98100. 